\title{
In vivo inhibition of inducible nitric oxide synthase by aminoguanidine influences free radicals production and macrophage activity in Trichinella spiralis infected low responders $(\mathrm{C} 57 \mathrm{BL} / 6)$ and high responders $(\mathrm{BALB} / \mathrm{c})$ mice
}

\author{
M. KOŁODZIEJ-SOBOCIŃSKA* ${ }^{1,2}$, B. MACHNICKA-ROWIŃSKA ${ }^{2}$
}

\author{
${ }^{1}$ Mammal Research Institute, Polish Academy of Sciences, Waszkiewicza 1, 17-230 Białowieża, Poland; \\ ${ }^{2}$ W. Stefański Institute of Parasitology, Polish Academy of Sciences, Twarda 51/55, 00-818 Warsaw, Poland, \\ *E-mail: mksobocinska@ibs.bialowieza.pl
}

\begin{abstract}
Summary
The influence of aminoguanidine (AG) - inhibitor of inducible nitric oxide synthase (iNOS), on macrophage activity and free radicals level was examined during Trichinella spiralis infection in two strains of mice: C57BL/6 and $\mathrm{BALB} / \mathrm{c}$. AG was administered either between $1-5$ days post infection (dpi) for intestinal phase examinations or between $16-29$ dpi for muscle phase examinations. The number of peritoneal macrophages and level of nitric oxide (NO) and hydrogen peroxide $\left(\mathrm{H}_{2} \mathrm{O}_{2}\right)$ in biological fluids were determined in both strains after infection or infection together with AG treatment as well as in control uninfected mice. The performed studies have proved, that free radicals play role in host immune response during intestinal and muscle phase of T.spiralis infection in mice. Inflammatory response in peritoneal cavity was delayed during infection in low responders $\mathrm{C} 57 \mathrm{BL} / 6$ mice in comparison with high responders $\mathrm{BALB} / \mathrm{c}$ mice. $\mathrm{C} 57 \mathrm{BL} / 6$ mice are Th-1 like strain and react stronger to $A G$ in contrary to $B A L B / c$ being Th-2 like strain. It was manifested as changes and fluctuations of free radicals levels and in the number of peritoneal macrophages after $\mathrm{AG}$ treatment in $\mathrm{C} 57 \mathrm{BL} / 6$ mice. A weak or no reaction on $A G$ injection in $B A L B / c$ mice is responsible for more stable and more effective defense response of the host to $T$. spiralis infection.
\end{abstract}

Keywords: Trichinella spiralis; aminoguanidine; nitric oxide; hydrogen peroxide; macrophages; strain of mice

\section{Introduction}

The aim of our studies was examination of the influence of free radicals: nitric oxide (NO) and hydrogen peroxide $\left(\mathrm{H}_{2} \mathrm{O}_{2}\right)$ on $T$. spiralis infection in mice. We used aminoguanidine $(\mathrm{AG})$ - inhibitor of inducible nitric oxide synthase (iNOS) for treatment of mice. The population of peritoneal macrophages was examined for the production of free radicals; the presence of NO was searched also in blood plasma and urine. Aminoguanidine (AG) selectively inhibits inducible nitric oxide synthase (Griffiths et al., 1993; Misko et al., 1993). Overall, AG has also antioxidant properties and exhibited a significant dose-dependent effect against oxygen free radicals damage (CouderotMasuyer et al., 1999). Modulation of free radicals production by AG treatment is a good tool for studying the role of these substances during trichinellosis, because only iNOSderived NO can play role in infected host organisms besides potential side-effects of AG administration are negligible (Misko et al., 1993). It is known that iNOS activity is changing during T. spiralis infection (Bian et al., 2001; Bian et al., 2005), so the inhibition of this enzyme by AG affects cytotoxic activity of macrophages, which could play role during infection. Our previous study showed that also macrophages play important role during intestinal phase of infection as well as revealed some new information about the role of free radicals during $T$. spiralis infection (Kołodziej-Sobocińska et al., 2006a,b) and reinfection (Kołodziej-Sobocińska et al., 2007).

$\mathrm{NO}$ is one of the free radicals, which plays crucial role in host defence, tissue pathology and in some autoimmune diseases (Singh et al., 2000; Bogdan, 2001). High levels of NO generated by iNOS have anti-microbial effects being the important factor of immune protection (Bogdan, 2001). Activated macrophages are able to produce high levels of iNOS derived NO as well as reactive oxygen species (ROS) such as: superoxide anion $\left(\mathrm{O}_{2}^{-}\right)$, hydrogen peroxide $\left(\mathrm{H}_{2} \mathrm{O}_{2}\right)$. NO can react with $\mathrm{O}_{2}{ }^{-}$to form peroxynitrate anions $\left(\mathrm{ONOO}^{-}\right)$, which rapidly decay to release highly reactive hydroxyl radicals (Beckman et al., 1990; Zhu et al., 1992). These reactive substances are very effective in killing infectious agents: viruses, bacteria, protozoa and fungi (Pacelli et al., 1995). The protective role of NO in Th-1inducing parasitic infections has been widely described (Liew et al., 1990; Liew, 1993; Rajan et al., 1996; Bhattacharjee et al., 2009; Cabrales et al., 2011). It has 
been also proved that NO can cause immunosuppression (Eisenstein et al., 1994; Rockett et al., 1994; Dai \& Gottstein, 1999; Ren et al., 2008) and tissue pathology (Garside et al., 1992; Kolb \& Kolb-Bachofen, 1992; Pacher et al., 2007). However, the role of NO in defence against $T$. spiralis and the other Th- 2 inducing infections such as helminthoses have not been yet completely explained (James, 1995; Liew et al., 1997; Alonso-Trujillo et al., 2007; Gruden-Movsesijan \& Sofronic-Milosavljevic, 2010). It is known that Th-2 immune response plays the main role during $T$. spiralis intestinal infection (Helmby \& Grencis, 2003; Reiterová et al., 1999; Dvorožňáková et al., 2010). Hogaboam et al. (1996) proved that during the intestinal phase of the infection Th-1 response is suppressed.

Differences in in vitro NO production caused by antigens from encapsulated and non-encapsulated Trichinella species have been previously studied (Andrade et al., 2007). Otherwise, our previously published data (Kołodziej-Sobocińska et al., 2006b) have revealed that in vivo inhibition of NO production by AG influenced the number of $T$. spiralis parasites in $\mathrm{BALB} / \mathrm{c}$ and $\mathrm{C} 57 \mathrm{BL} / 6$ mice. It has occurred that $A G$ treatment during intestinal phase of the infection caused opposite effects in two strains of mice. In $\mathrm{BALB} / \mathrm{c}$ mice the diminution of adult worms was observed but in C57BL/6 mice the number of adult worms was even higher. The treatment of mice with $\mathrm{AG}$ at the beginning of muscle phase of infection caused that fewer larvae settled in mice muscles (Kołodziej-Sobocińska et al., 2006b).

In presented here examinations, similarly as in the quoted above experiment, two genetically and immunologically different strains of mice were used. The strain-specific differences in immunological response during nematode infection are known (Brown et al., 2003). BALB/c mice (high responders) belonging to "Th2-like" strains, possessing M-2 macrophages, which can influence mainly Th2 response and having small ability to produce NO (Mills et al., 2000). The mice of BALB/c strain respond rapidly to T. spiralis infection. The mice of strain C57BL/6 (low responders), belonging to "Th1-like" strains, having M-1 macrophages, more susceptible to produce $\mathrm{NO}$ and promoting mainly Th-1 response (Mills et al., 2000). These mice respond slowly to infection with $T$. spiralis. The strain differences can be helpful in explanation of mice responsiveness to free radicals production after $T$. spiralis infection as well as AG administration.

\section{Material and methods}

\section{Experimental animals}

The experiments were carried out on $84 \mathrm{C} 57 \mathrm{BL} / 6$ and 84 $\mathrm{BALB} / \mathrm{c}$ mice; 6 week old males orally infected with 400 T. spiralis larvae. Control groups consisted of uninfected mice, of the same age, untreated or treated with AG. Animals matched for age, weight and gender were housed under standard conditions $\left(20-21{ }^{\circ} \mathrm{C}, 50-60 \%\right.$ relative humidity, and $12 \mathrm{~h}$ light regime). They were fed ad libitum with AIN-76 diet (ICN Biomedicals) with the constant nitrite and nitrate contents to exclude fluctuations of NO le- vels in biological material connected with animals feeding. The larvae used in the infection were recovered from muscles of rats infected $2-3$ months earlier by digestion with $1 \%$ pepsin $/ \mathrm{HCl}$ solution for $4 \mathrm{~h}$ at $37^{\circ} \mathrm{C}$. The strain determined in Instituto Superiore di Sanita, Rome, Italy as $T$. spiralis sensu stricto T1 was maintained in W. Stefański Institute of Parasitology of the Polish Academy of Sciences since 1962 by serial passages in rats and was isolated originally from swine.

All procedures were performed in compliance with relevant Polish low and institutional guidelines. All procedures were approved by the appropriate institutional committee.

\section{Experimental schedule}

In the first experiment there were 4 experimental groups. The first group ("infected+AG") consisted of 12 C57BL/6 and $12 \mathrm{BALB} / \mathrm{c}$ infected mice, which were injected intraperitoneally with $50 \mathrm{mg} / \mathrm{kg}$ body weight (bw) of AG (Sigma-Aldrich, Germany) in $0.1 \mathrm{ml}$ phosphate buffer saline (PBS) (Biomed, Poland) / 1 mouse. These mice were injected once a day at the beginning of the $T$. spiralis infection, from the $1^{\text {st }}$ to the $5^{\text {th }}$ days post infection (dpi). The second group ("infected") consisted of 12 C57BL/6 and 12 $\mathrm{BALB} / \mathrm{c}$ infected mice which were injected with $0.1 \mathrm{ml} / 1$ mouse of PBS (Biomed, Poland) only. Two control uninfected groups ("uninfected $+\mathrm{AG}$ " and "uninfected") consisted of $12 \mathrm{C} 57 \mathrm{BL} / 6$ and $12 \mathrm{BALB} / \mathrm{c}$ mice each; treated with AG or PBS respectively with the same dose and volume as infected mice. Examinations were done at 6, 9, 15 and $20 \mathrm{dpi}$ and the biological material was collected.

The second experiment consisted of the same four experimental groups: "infected $+A G$ ", "infected", "uninfected + AG", "uninfected". Muscle phase of the infection was examined in 36 mice from each strain, which were injected once a day with AG or PBS at the beginning of muscle phase of T. spiralis infection from the $16^{\text {th }}$ to the $29^{\text {th }}$ dpi. Doses of AG and the volume of intraperitoneal injections were the same as in the first experiment. These mice were examined at 30, 35 and $41 \mathrm{dpi}$ and the biological material was collected.

\section{Blood and urine sample collection}

Blood samples taken from the hearts of anaesthetized mice and collected in heparinized tubes were centrifuged at $1.500 \mathrm{x} \mathrm{g}$ for $10 \mathrm{~min}$. Plasma samples were stored frozen until further examination. Urine was taken from live animals and kept frozen for detection of NO.

\section{Peritoneal macrophages}

Macrophages were purchased from the peritoneal cavity by washing with $5 \mathrm{ml}$ of phenol red-free Hanks' Balanced Salt Solution (HBSS) (Sigma-Aldrich, Germany). Cells were washed three times in phenol red-free HBSS, centrifuged at $170 \mathrm{x} \mathrm{g}$ for $10 \mathrm{~min}$ at $4{ }^{\circ} \mathrm{C}$ and the cell pellet was resuspended in RPMI 1640 medium (Sigma-Aldrich, Germany). The total number of cells and the number of macrophages isolated from peritoneal cavity were determined using a Bürker counting chamber. The viability of the cells was 
assessed using the Trypan Blue (Sigma-Aldrich, Germany) exclusion assay.

\section{Cultivation of peritoneal macrophages}

Cells obtained from peritoneal cavity in $3 \mathrm{ml}$ of sterile RPMI 1640 medium (Sigma-Aldrich, Germany) containing $10 \%$ Fetal Calf Serum (FCS) (Sigma-Aldrich, Germany) were placed onto sterile plastic Petri dishes (Medlab Products, Poland) and incubated for $1.5 \mathrm{~h}$ at $37^{\circ} \mathrm{C}$ in $5 \% \mathrm{CO}_{2}$. Next, the nonadherent cells were removed, peritoneal macrophages were washed twice with RPMI 1640 medium containing $10 \% \mathrm{FCS}$ and suspended in the cultivation medium: RPMI $1640+10 \%$ FCS + penicillin G (100 $\mathrm{U} / \mathrm{ml})+$ streptomycin $(100 \mu \mathrm{g} / \mathrm{ml})$. The cultivation of macrophages was carried out for $48 \mathrm{~h}$ at $37{ }^{\circ} \mathrm{C}$ in $5 \% \mathrm{CO}_{2}$. Then, the culture supernatants were collected and frozen for the determination of NO level.

Detection of NO level in supernatants after peritoneal macrophages cultivation

Nitrite concentration in the supernatants was measured by a microplate assay method described by Ding et al. (1988). Briefly, to $100 \mu \mathrm{l}$ of supernatant obtained from peritoneal macrophages cultivation, $100 \mu \mathrm{l}$ of Griess reagent $(1 \%$ sulphanilamide in $5 \% \mathrm{H}_{3} \mathrm{PO}_{4} ; 0.1 \% \mathrm{~N}$-(1-naphthyl) ethylenediamine dihydrochloride in $5 \% \mathrm{H}_{3} \mathrm{PO}_{4} ; 1 \mathrm{vol} / 1 \mathrm{vol}$ ) (Sigma-Aldrich, Germany) was added. Probes were incubated at room temperature for 10 minutes. The absorbance of triplicate samples at $540 \mathrm{~nm}$ was determined in an Organon Teknika microplate reader (Netherlands). NO concentration in the samples was calculated with reference to a sodium nitrite standard curve of range $0-120 \mu \mathrm{M}$ and expressed in $\mu \mathrm{M}$ of nitrite.

\section{Detection of NO level in plasma and urine}

The amount of NO was assayed using the method of Rockett et al. (1994).

Briefly, to $30 \mu \mathrm{l}$ of sample, $15 \mu \mathrm{l}$ of Nicotinamide Adenine Dinucleotide Phosphate (NADPH) $(1.25 \mathrm{mg} / \mathrm{ml})$ (SigmaAldrich, Germany) and $5 \mu$ of nitrate reductase $(5 \mathrm{U} / \mathrm{ml})$ (Sigma-Aldrich, Germany) were added. Samples were incubated for 20 minutes at room temperature. Then, 100 $\mu \mathrm{l}$ of Griess reagent and $100 \mu \mathrm{l}$ of $10 \%$ trichloroacetic acid were added to each sample. Samples were centrifuged at $1400 \times \mathrm{g}$ for 15 minutes at room temperature. $200 \mu \mathrm{l}$ of supernatants were transferred to 96 well microplates (Nunc, Denmark). The absorbance of duplicate samples was measured at $540 \mathrm{~nm}$ using an automatic reader (Organon Teknika, Netherlands). The amount of NO was defined from the standard curve of reduced $\mathrm{NaNO}_{3}$. The results were expressed in $\mu \mathrm{M}$ of nitrite.

\section{Microassay of hydrogen peroxide production}

Hydrogen peroxide production by peritoneal macrophages was measured by a microplate assay method described by Pick, (1986). This assay is based on the horseradish peroxidase-dependent oxidation of phenol red by $\mathrm{H}_{2} \mathrm{O}_{2}$ lead- ing to the formation of a compound that, at an alkaline $\mathrm{pH}$, exhibits increased absorbance at $600 \mathrm{~nm}$.

Briefly, cells suspension obtained from peritoneal cavity in $200 \mu \mathrm{l}$ of sterile RPMI 1640 medium (Sigma-Aldrich, Germany) containing $10 \%$ FCS (Sigma-Aldrich, Germany) were placed onto 96-well flat bottom microplates in duplicate (Nunc, Denmark). Cells were incubated for $1.5 \mathrm{~h}$ at $37^{\circ} \mathrm{C}$ in $5 \% \mathrm{CO}_{2}$. After the incubation, the nonadherent cells were removed, peritoneal macrophages were washed twice in phenol red-free HBSS and the adherent cells were covered with $200 \mu \mathrm{l} /$ well solution of $0.56 \mathrm{mM}$ phenol red (Sigma Aldrich, Germany) and $20 \mathrm{U} / 1 \mathrm{ml}$ horseradish peroxidase type II (HRPO) (Sigma Aldrich, Germany) in HBSS. The plates were covered with lids and incubated for $1 \mathrm{~h}$ at $37^{\circ} \mathrm{C}$ in $5 \% \mathrm{CO}_{2}$. Then, the reaction was interrupted by adding $20 \mu \mathrm{l} /$ well of $1 \mathrm{~N} \mathrm{NaOH}$. This step induced immediate cell death with consequent interruption of $\mathrm{H}_{2} \mathrm{O}_{2}$ production. The absorbance at $600 \mathrm{~nm}$ was read and $\mathrm{H}_{2} \mathrm{O}_{2}$ concentration in the samples was calculated with the reference to $\mathrm{H}_{2} \mathrm{O}_{2}$ standard curve of range 0-100 $\mu \mathrm{M}$. Results were finally expressed as nanomoles $\mathrm{H}_{2} \mathrm{O}_{2}$ per $10^{6}$ cells per time interval using the formula:

nanomoles $\mathrm{H}_{2} \mathrm{O}_{2}$ per well $=$ Abs at $600 \mathrm{~nm} \times 16.7$.

\section{Statistical analysis}

Data are presented as means \pm SEM. The aim of the statistical analysis was evaluation of the differences among mean values of investigated biological parameters concerning: (1) two strains of mice; (2) infection T. spiralis versus control uninfected; (3) treatment of $A G$ versus no treatment; (4) days after infection.

Main effects of 4 analysed factors and their all interactions were evaluated by 4-way analysis of variance (ANOVA) method. Hypotheses on main effects and interaction were tested by F-Fisher-Snedecor test. Multiple comparisons of significant effects were performed by least significant difference (LSD) based on t-Student test. The differences among the groups were considered significant at the value $\mathrm{p}<0.05$.

\section{Results}

Number of mice peritoneal macrophages during intestinal phase of infection

Infection with $T$. spiralis caused significantly elevated number of peritoneal macrophages in mice of both strains $(* * * \mathrm{p}<0.001)$, which continuously increased from $6^{\text {th }}$ till $20^{\text {th }}$ dpi $(* * * \mathrm{p}<0.001)$. There were more peritoneal macrophages in $\mathrm{C} 57 \mathrm{BL} / 6$ mice infected with $T$. spiralis than in $\mathrm{BALB} / \mathrm{c}$ mice $(* * * \mathrm{p}<0.001)$. AG injections from $1^{\text {st }}$ to $5^{\text {th }}$ dpi caused diminution of peritoneal macrophage number in infected C57BL/6 mice at 6 and 9 dpi, just after AG treatment, and elevation of number of these cells at 15 and 20 dpi $(* p<0.05)$ (Fig. 1b). AG injections had no influence on macrophage number in peritoneal cavity of infected BALB/c mice (Fig. 1a) and uninfected mice of both strains during intestinal phase of $T$. spiralis infection. 
a

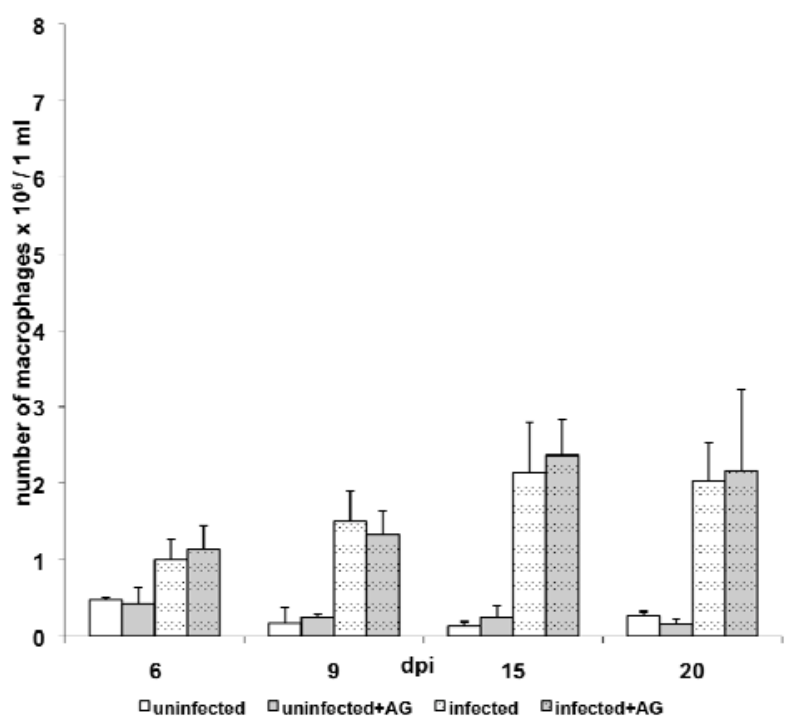

b $\quad$ C57BL/6

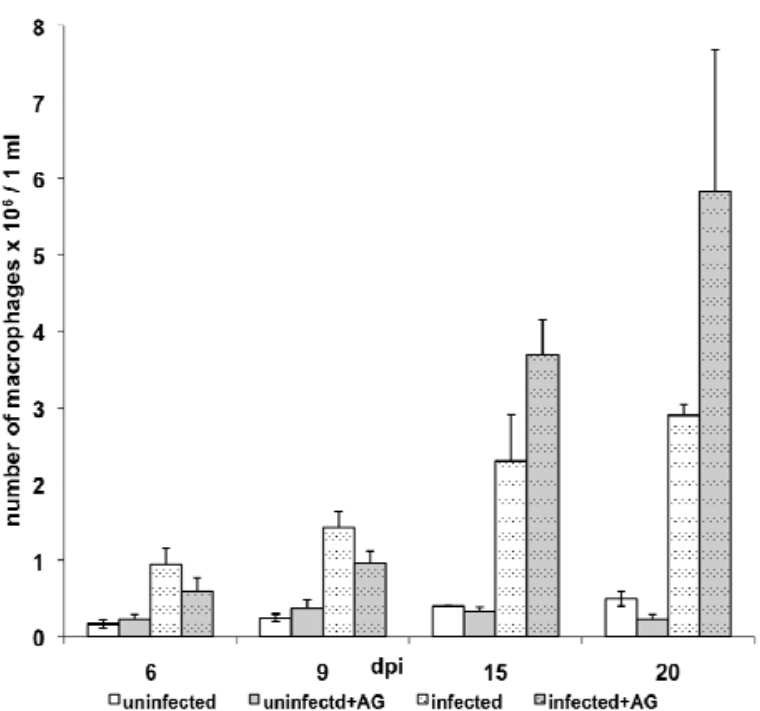

Fig. 1. Number of macrophages in peritoneal cavity of mice during intestinal phase of $T$. spiralis infection. Comparison of results from two strains of mice: BALB/c mice (a) and C57BL/6 mice (b) after infection with $T$. spiralis and with or without AG treatment between 1 and 5 dpi. $n=4$

Number of mice peritoneal macrophages during muscle phase of infection

Infection with $T$. spiralis caused significant elevation of peritoneal macrophage number in mice of both strains $(* * * p<0.001)$ during early muscle phase of the infection. In C57BL/6 mice infected with $T$. spiralis there were more peritoneal macrophages than in BALB/c mice $(* * * p<$ $0.001)$. AG injections from $16^{\text {th }}$ to $29^{\text {th }}$ dpi caused diminution of peritoneal macrophages number in infected C57BL/6 mice $(* * * p<0.001)$ (Fig. 2b). AG injections had no influence on macrophages number in peritoneum of infected BALB/c mice (Fig. 2a) and uninfected mice of both strains during muscle phase of $T$. spiralis infection.
The nitric oxide production by mice peritoneal macrophages during intestinal phase of infection

Peritoneal macrophages isolated from C57BL/6 mice produced more NO than from BALB/c mice $(* * * p<0.001)$. Infection of C57BL/6 mice with $T$. spiralis caused higher NO production in comparison to uninfected, untreated with AG mice $(* p<0.05)$ (Fig. 3b). AG injections caused diminution of NO production in infected mice of both strains as well as in uninfected BALB/c mice. However, higher NO production after $\mathrm{AG}$ treatment in uninfected $\mathrm{C} 57 \mathrm{BL} / 6$ mice was observed $(* * * p<0.001)$ (Fig. $3 b)$. The level of NO production continuously decreased and at 20 dpi NO production was very low in animals from all experimental groups $(* \mathrm{p}<0.05)$. (Fig. 3a-b).
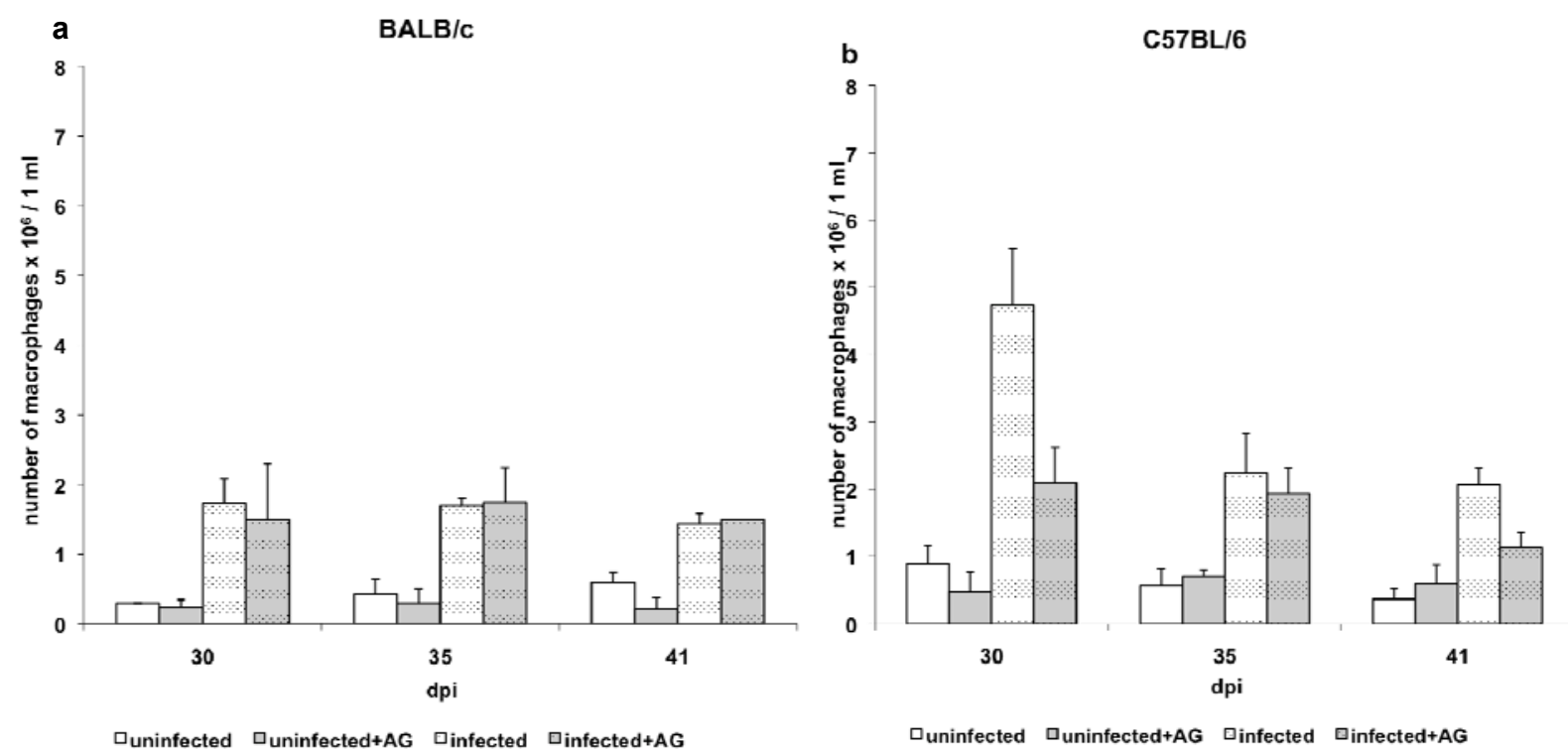

Fig. 2. Number of macrophages in peritoneal cavity of mice during muscle phase of $T$. spiralis infection. Comparison of results from two strains of 192 mice: BALB/c mice (a) and C57BL/6 mice (b) after infection with $T$. sviralis and with or without AG treatment between 16 and 29 dpi. $\mathrm{n}=4$ 

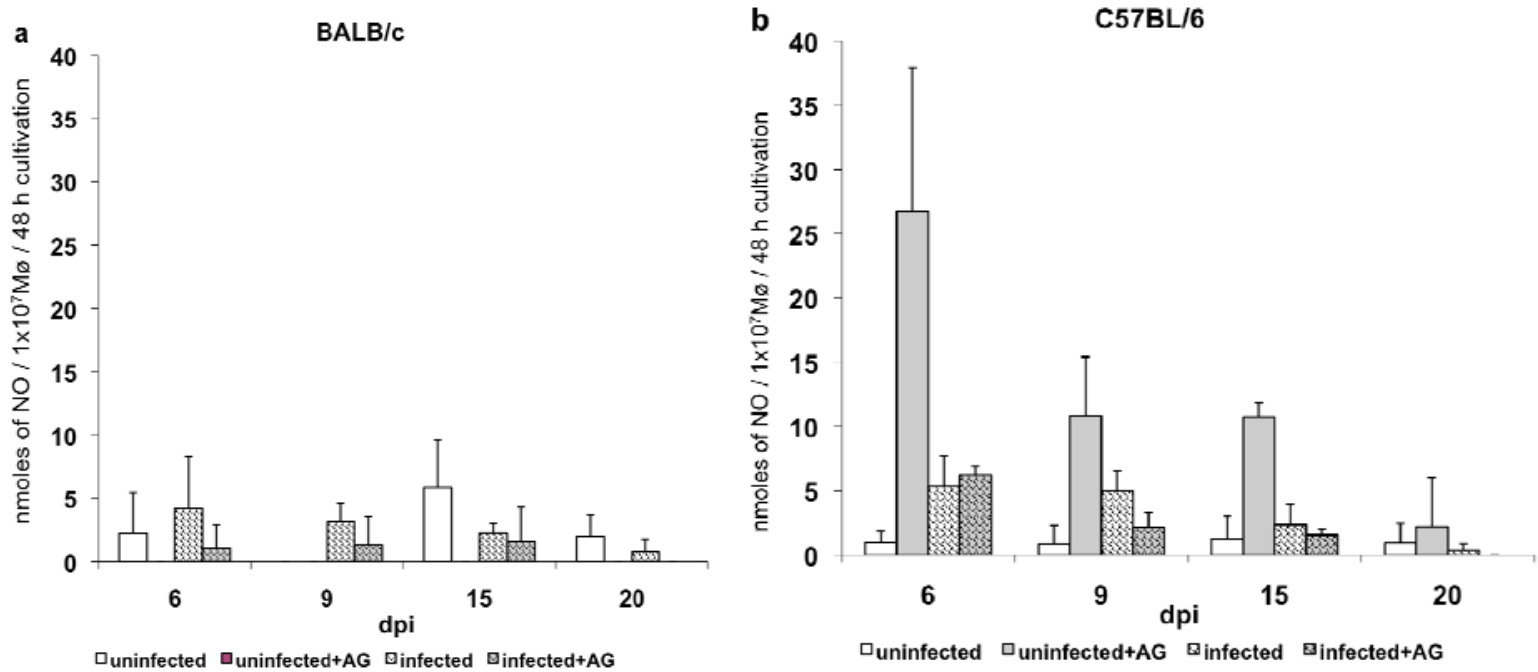

Fig. 3. The production of nitric oxide by peritoneal macrophages during intestinal phase of $T$. spiralis infection. Comparison of results from two strains of mice: BALB/c mice (a) and C57BL/6 mice (b) after infection with $T$. spiralis and with or without AG treatment between 1 and 5 dpi. $\mathrm{n}=4$

The nitric oxide production by mice peritoneal macrophages during muscle phase of infection

None of studied factors had statistical significant influence on NO production by peritoneal macrophages during muscle phase of $T$. spiralis infection. Only the tendency of lower NO production by macrophages isolated from infected mice of both strains was observed $(p=0.058)$ (Fig.4a-b)

The hydrogen peroxide production by mice peritoneal macrophages during intestinal phase of infection

Peritoneal macrophages isolated from infected mice of both strains produced less $\mathrm{H}_{2} \mathrm{O}_{2}$ than from uninfected mice during the whole intestinal phase of infection $(* * * p<$ 0.001). Additionally, $\mathrm{AG}$ treatment of infected mice caused inhibition of $\mathrm{H}_{2} \mathrm{O}_{2}$ production but in uninfected mice the stimulation of $\mathrm{H}_{2} \mathrm{O}_{2}$ production was observed $(* \mathrm{p}$ $<0.05)$ (Fig. 5a-b).

The hydrogen peroxide production by mice peritoneal macrophages during muscle phase of infection

The strong inhibition of $\mathrm{H}_{2} \mathrm{O}_{2}$ production by peritoneal macrophages of infected mice of both strains was observed during muscle phase of infection $\left({ }^{*} p<0.05\right)$. AG treatment caused elevated $\mathrm{H}_{2} \mathrm{O}_{2}$ production in macrophages of both uninfected and infected mice $(* p<0.05)$ (Fig. 6a-b).

Level of NO in plasma during intestinal phase of infection $\mathrm{AG}$ treatment of C57BL/6 mice caused lower NO level in plasma at the beginning of the experiment in comparison to $\mathrm{BALB} / \mathrm{c}$ mice treated with $\mathrm{AG}$ at the same time $(* \mathrm{p}<0.05)$. Later, during intestinal phase of $T$. spiralis infection, NO
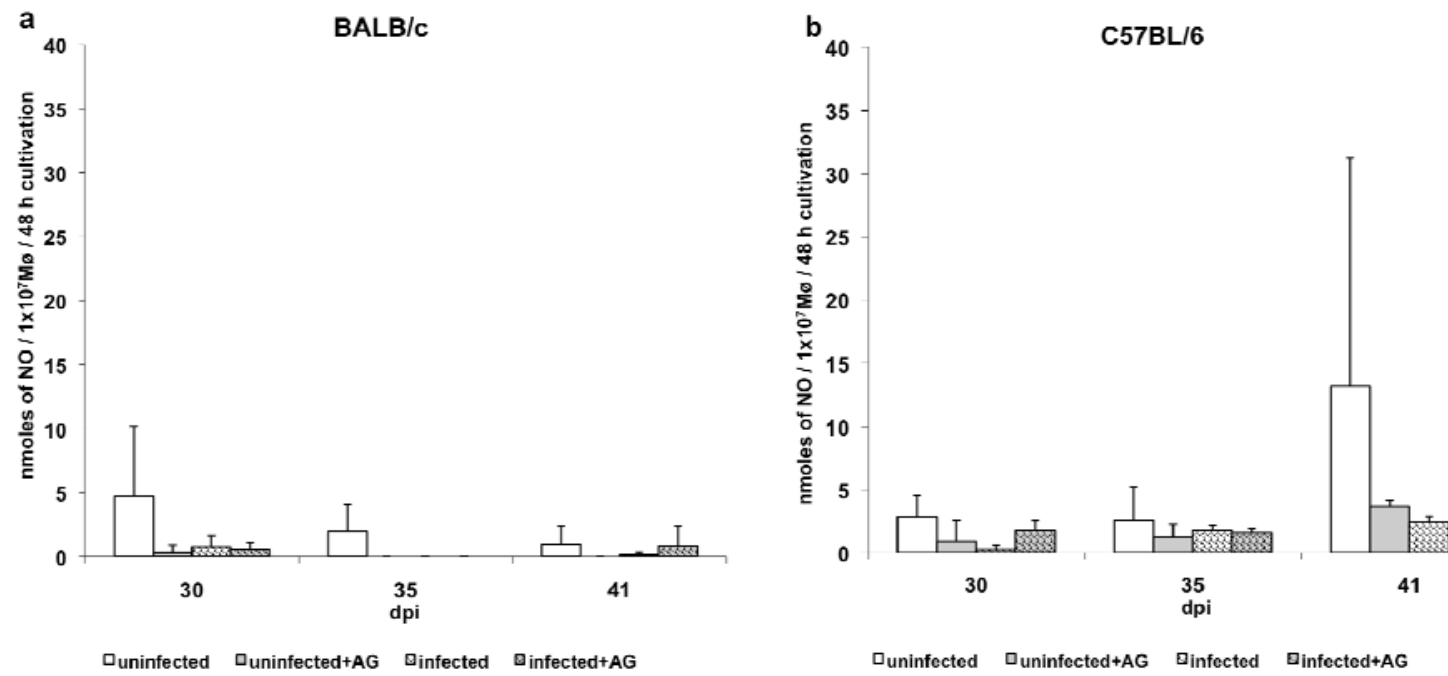

Fig. 4. The production of nitric oxide by peritoneal macrophages during muscle phase of T. spiralis infection. Comparison of results from two strains of mice: BALB/c mice (a) and C57BL/6 mice (b) after infection with $T$. spiralis and with or without AG treatment between 16 and 29 dpi. $n=4$ 
a

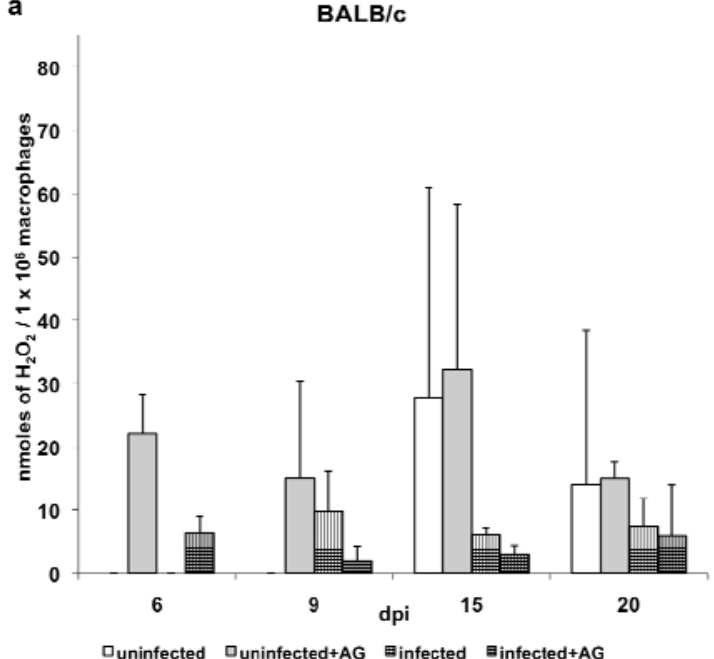

b

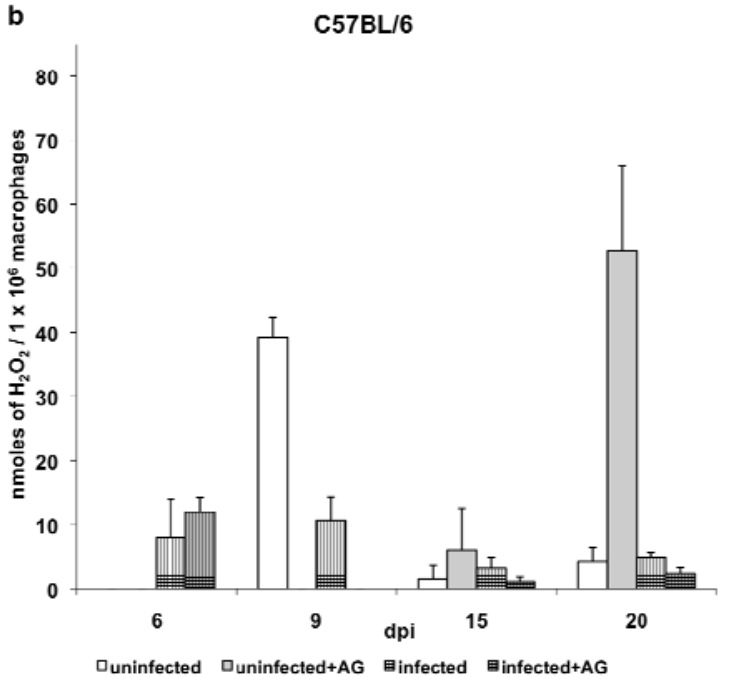

Fig. 5. The production of hydrogen peroxide by peritoneal macrophages during intestinal phase of T. spiralis infection. Comparison of results from two strains of mice: BALB/c mice (a) and C57BL/6 mice (b) after infection with $T$. spiralis and with or without AG treatment between 1 and 5 dpi. $n=4$

level was rising in plasma of C57BL/6 mice and was decreasing in plasma of BALB/c mice $(* * * p<0.001)$ (Fig. 7a-b).

\section{Level of NO in plasma during muscle phase of infection} Elevated NO level in plasma of infected mice in comparison to uninfected mice, both untreated with AG, was observed at 30 and 41 dpi in BALB/c mice (Fig. 8a) and at 35 and $41 \mathrm{dpi}$ in C57BL/6 mice (Fig. 8b). AG treatment caused higher NO level only in plasma of uninfected mice of both strains $(* p<0.05)$.

\section{Level of NO in urine during intestinal phase of infection} In both strains of mice the level of NO in urine of infected animals was lower in comparison to uninfected controls during intestinal phase of the infection. Additionally, ana- lysis of this parameter has shown strong interdependence of time and this free radical level. The strongest decreasing of $\mathrm{NO}$ level in urine during the experiment was observed in infected BALB/c mice $(* * * p<0.001)$ (Fig. 9a). On the contrary, in infected $\mathrm{C} 57 \mathrm{BL} / 6$ mice treated with $\mathrm{AG}$ the level of NO was increasing and it was the highest at the end of intestinal phase of the infection $(* * * p<0.001)$ (Fig. $9 b)$. Treatment of infected mice with AG causes higher NO level in urine.

Level of NO in urine during muscle phase of infection Analysis of NO level in mice urine during muscle phase of the infection has shown strong interdependence of time and this free radical level in mice infected with $T$. spiralis. In infected BALB/c mice untreated with $A G$ the level of NO was increasing significantly $(* p<0.05)$ but was lower
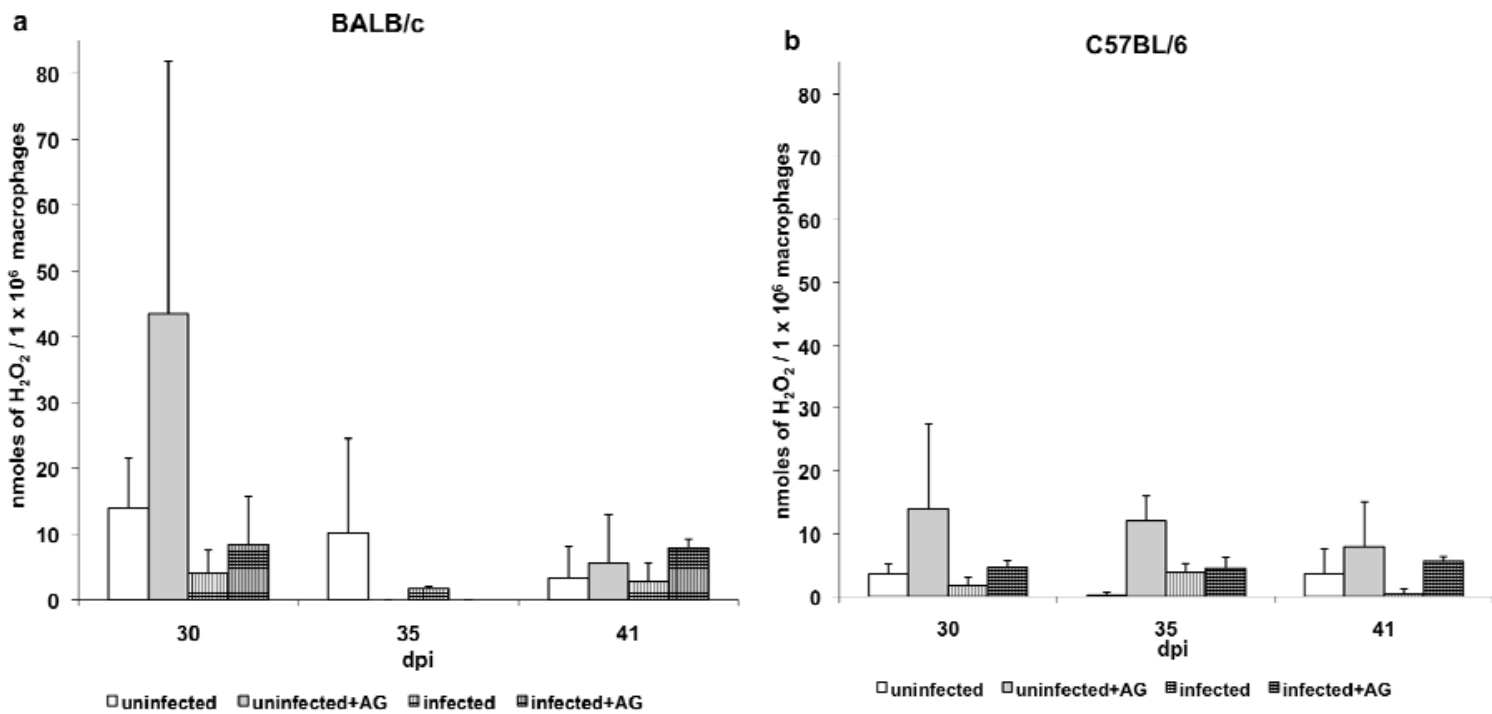

Fig. 6. The production of hydrogen peroxide by peritoneal macrophages during muscle phase of T. spiralis infection. Comparison of results from two strains of mice: BALB/c mice (a) and C57BL/6 mice (b) after infection with T. spiralis and with or without AG treatment 

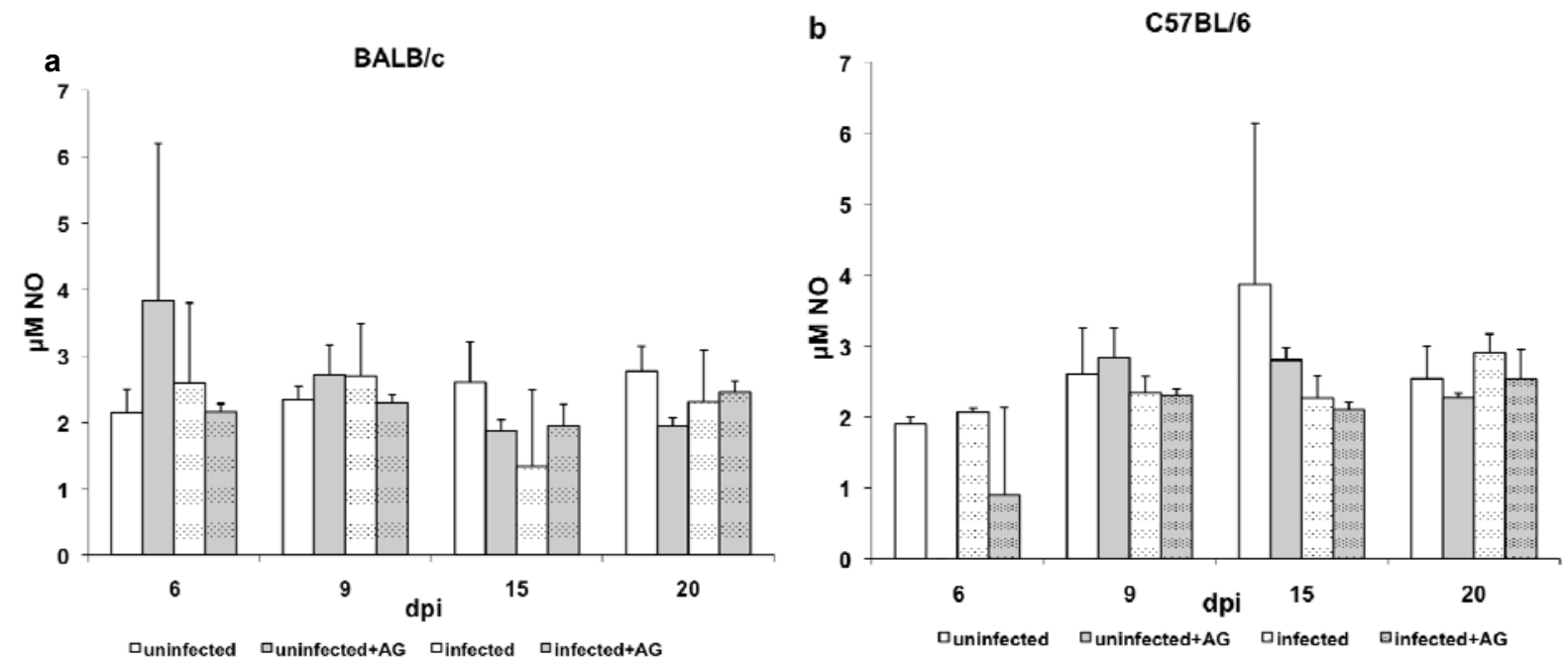

Fig. 7. Level of nitric oxide in plasma of mice during intestinal phase of $T$. spiralis infection. Comparison of results from two strains of mice: BALB/c mice (a) and C57BL/6 mice (b) after infection with T. spiralis with or without AG treatment between 1 and 5 dpi. $\mathrm{n}=4$

in comparison to control uninfected mice (Fig. 10a). In C57BL/6 mice the level of NO in urine of infected animals was also increasing significantly but only in mice untreated with AG $(* * * p<0.001)$ (Fig. 10b). Treatment of infected mice with $A G$ had no statistical significantly influence on NO level in mice urine. In uninfected mice of both strains the level of NO in urine was constant and no statistical significant differences were observed.

\section{Discussion}

The aim of the performed study was to examine the influence of free radicals: nitric oxide and hydrogen peroxide on $T$. spiralis infection in mice. Two strains of mice: $\mathrm{C} 57 \mathrm{BL} / 6$ and $\mathrm{BALB} / \mathrm{c}$, which differ in immunological response, where used. Also the influence of aminoguani- dine - inhibitor of inducible nitric oxide synthase on the cytotoxic immune response was studied.

It is known that activated macrophages produce among others, highly reactive inorganic compounds, which are toxic for pathogens. However, little is known about their role in defense against $T$. spiralis infection. The performed studies have proved that free radicals take part in the host immune response during both intestinal and muscle phase of $T$. spiralis infection in mice.

Infection of mice belonging to both strains resulted in elevation of the number of peritoneal macrophages, even during muscle phase of the infection (Figs. 1 and 2). It is adverse parallel to the number of adult parasites in mice of both strains but more pronounced in $\mathrm{C} 57 \mathrm{BL} / 6$ mice (Kołodziej-Sobocińska et al., 2006b). The changes in macrophages number in time was observed only in $\mathrm{C} 57 \mathrm{BL} / 6$
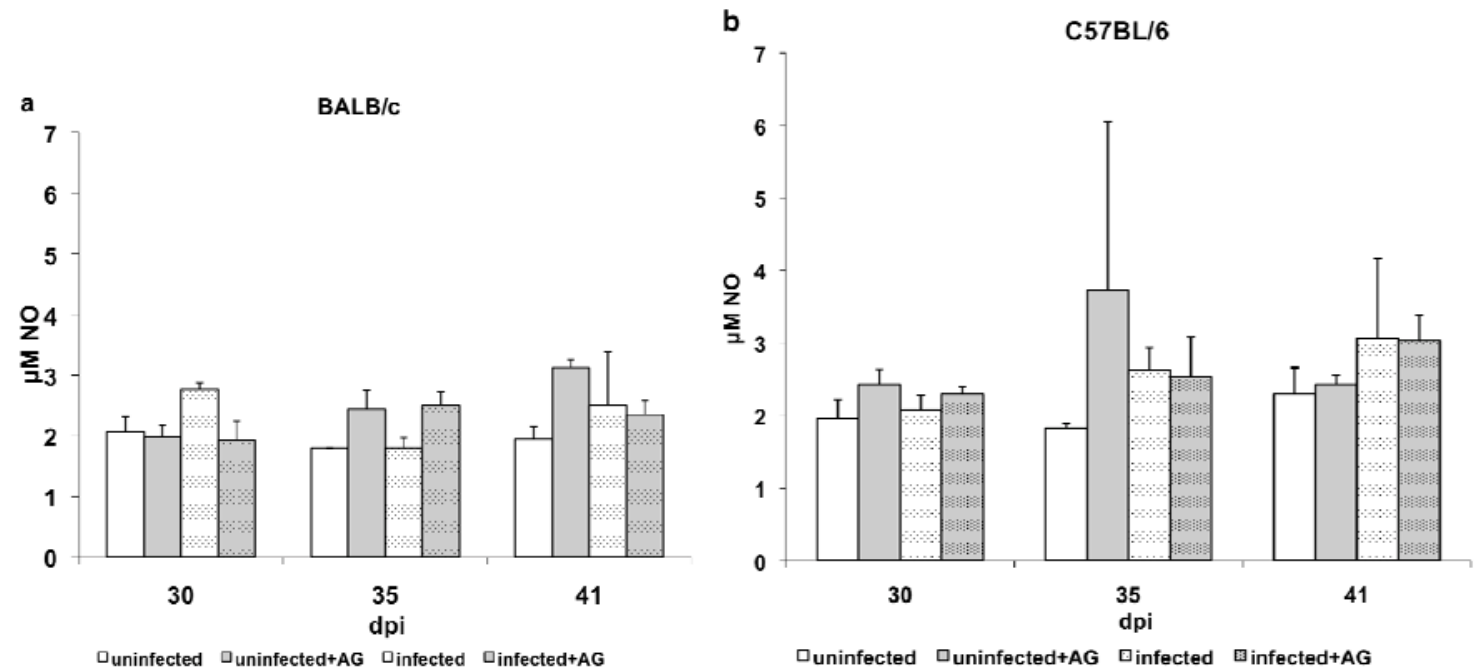

Fig. 8. Level of nitric oxide in plasma of mice during muscle phase of T. spiralis infection. Comparison of results from two strains of mice: BALB/c mice (a) and C57BL/6 mice (b) after infection with T. spiralis with or without AG treatment between 16 and $29 \mathrm{dpi}$. $\mathrm{n}=4$ 

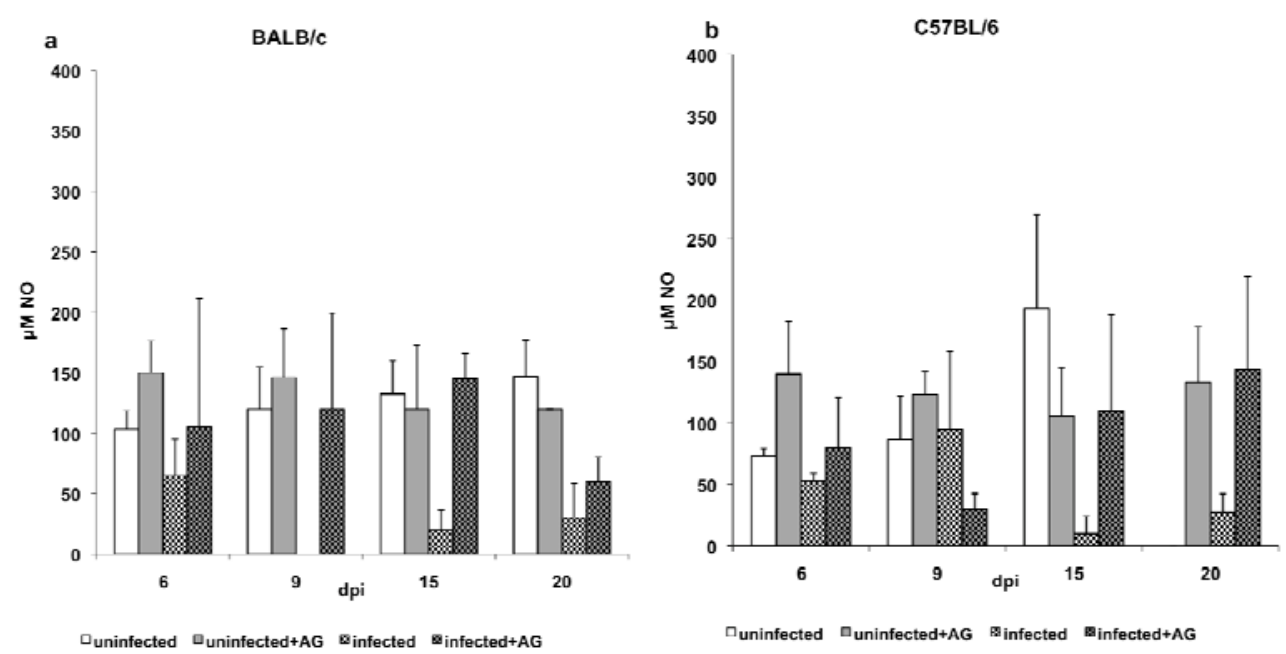

Fig. 9. Level of nitric oxide in urine of mice during intestinal phase of $T$. spiralis infection. Comparison of results from two strains of mice: BALB/c mice (a) and C57BL/6 mice (b) after infection with $T$. spiralis with or without AG treatment between 1 and 5 dpi. $\mathrm{n}=4$

infected mice, where the highest numbers of these cells were observed from 15 till $30 \mathrm{dpi}$, and then their significant drop was observed (Figs. 1 and 2). In BALB/c infected mice the number of macrophages was also higher in comparison to uninfected controls, but the values were stable during the all experiment. Interestingly, the inflammatory response with high number of macrophages is strongly activated after early $\mathrm{AG}$ treatment of infected C57BL/6 mice (Fig.1b). In uninfected mice treated with AG such reaction is not observed, so it is unquestionable that both factors together: T. spiralis infection and $\mathrm{AG}$ treatment caused this reaction. Unexpectedly, in $\mathrm{C} 57 \mathrm{BL} / 6$ mice treated with $\mathrm{AG}$ in the early muscle phase of the infection the number of macrophages was much lower (Fig. 2b), whether AG treatment of these mice at the beginning of $T$. spiralis infection caused higher macrophages number (Fig. 1b). The role of NO production modulators in therapy of other diseases is known (Morley \& Flood, 1991; Cooke \& Tsao, 1992; Cayatte et al., 1994; Olesen et al., 1994). So, the probe of the recognition of AG role in trichinellosis could be also important for probable therapy. AG treatment of infected mice of both strains (BALB/c, $\mathrm{C} 57 \mathrm{BL} / 6$ ) caused that less muscle larvae settled in muscles. In C57BL/6 mice infected with $T$. spiralis but untreated with $\mathrm{AG}$ the highest muscle larvae number was observed at $30 \mathrm{dpi}$ and, then strong reduction of muscle larvae was observed till 41 dpi (Kołodziej-Sobocińska et al., 2006b). It could be explained by stronger activation of cytotoxic mechanisms in this Th1-like strain. It is known that macrophages are present in the neighborhood of larvae in muscles for a long time (Dąbrowska et al., 2004) and that they play role in elimination of larvae from muscles of infected host. The role of Th- 2 response and secretion of Th2-cytokines (IL-4, IL-5, IL-9, IL-10, IL-13) by activated
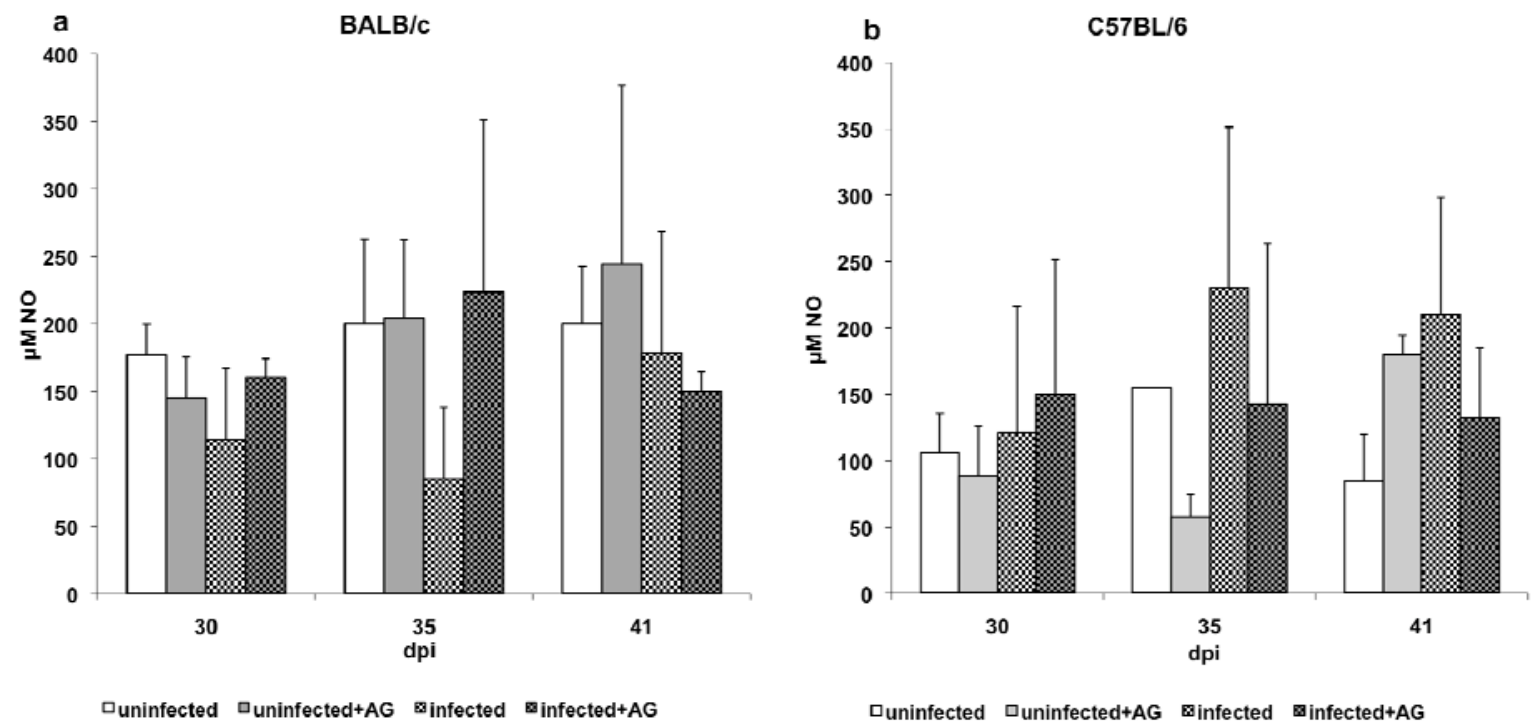

Fig. 10. Level of nitric oxide in urine of mice during muscle phase of T. spiralis infection. Comparison of results from two strains of mice: BALB/c mice (a) and C57BL/6 mice (b) after infection with T. spiralis with or without AG treatment between 16 and 29 dpi. $\mathrm{n}=4$ 
lymphocytes, during intestinal phase of $T$. spiralis infection has been proved (Faulkner et al., 1997; Urban et al., 2000; Khan et al., 2001; Helmby \& Grencis, 2003). Recently published by Dvorožňáková et al. (2011) results showed the increased Th-2 response at the intestinal phase (elevated level of IL-5 and IL-10) in mice infected with small doses of both: encapsulating (T. spiralis, T.britovi) and non-encapsulating (T. pseudospiralis) species of Trichinella, what simulates infections naturally occurred in the environment. However, it has also occurred that at the beginning of $T$. spiralis infection also cytotoxic immune response is activated. Karmańska et al. (1997) detected macrophages in gut mucosa at $7 \mathrm{dpi}$ in infected with $T$. spiralis mice. The immunological reaction in peritoneal cavity could be caused by the newborn larvae migration through body cavities. Shanta and Meerovith, (1967) detected $T$. spiralis newborn larvae in peritoneal cavity between 6 and 25 dpi, when we observed very high number of peritoneal macrophages (Fig. 1). Inflammatory reaction in peritoneal cavity is strongly delayed in low responders mice (C57BL/6). It seems to be connected with worm expulsion, which is also delayed in this strain of mice in comparison to high responders mice (BALB/c) (KołodziejSobocińska et al., 2006b). Similarly, from the $15^{\text {th }}$ dpi the increasing of IFN- $\gamma$ level (Th-1 response) was observed in experimentally infected with small doses of three Trichinella species (T. spiralis, T. britovi, T. pseudospiralis) mice, what is connected with persistence of migrating newborn larvae at this time of the infection (Dvorožňáková et al., 2011).

During T. spiralis infection macrophages isolated from peritoneal cavity of $\mathrm{C} 57 \mathrm{BL} / 6$ mice produced more $\mathrm{NO}$ than from BALB/c mice (Figs. 3 and 4). C57BL/6 mice are Th1-like strain, where are present M-1 macrophages, which produce high levels of NO after activation (Mills et al., 2000). It could be suspected that AG also easily inhibits these cells and they do not produce NO. Therefore, the compensation of interrupted cytotoxic response is needed and more macrophages migrate into peritoneal cavity of infected animals. These suggestion has been proved by our studies, because indeed high number of macrophages after AG treatment of infected mice does not correlate with high level of $\mathrm{NO}$ as well as $\mathrm{H}_{2} \mathrm{O}_{2}$ at the beginning of infection (Figs. 3 and 5). The highest activation of NO production in peritoneal cavity of infected, untreated mice was observed at 6 and 9 dpi (Fig. 3). Bian et al. (2001) observed high iNOS expression in intestine of $T$. spiralis infected mice but only during first 3 dpi. The reaction in peritoneal cavity is delayed in comparison to reaction activated in intestine of mice infected with $T$. spiralis. That could be the reason of high iNOS expression till 3 dpi in intestine (Bian et al., 2001) and higher NO production by peritoneal macrophages from 6 dpi in our studies. Later, during muscle phase of $T$. spiralis infection, AG treatment of C57BL/6 infected mice caused diminution of macrophages number (Fig. 2b), these cells produced more NO at 30 dpi (Fig. 4b) and $\mathrm{H}_{2} \mathrm{O}_{2}$ at 30 and 41 dpi (Fig. 6b) in comparison to infected but untreated with AG mice. It could be explained by the compensation, when small number of cells under inflammatory conditions elicited by $T$. spiralis infection are forced to produce more free radicals to make the immune response as strong as it is necessary for the host defense. So, it is suggested that the differences in both: free radicals production and the number of macrophages observed after AG treatment in two strains of mice are related to the host immune response caused by parasite infection but not to $\mathrm{AG}$ mode of action. BALB/c mice infected with $T$. spiralis as well as control uninfected animals do not react to AG treatment (Fig. 2). During the early muscle phase of $T$. spiralis infection in the neighborhood of nurse-cell the presence of CD4+, CD8+ lymphocytes as well as macrophages was stated (Karmańska et al., 1997). In muscles the presence of iNOS was also stated (Boczoń et al., 2004) but it is known that expression of iNOS mRNA as well as iNOS presence in tissues do not testify to NO persistence (Luss et al., 1994; Luss et al., 1997). The studies of the influence of $A G$ on both NO and $\mathrm{H}_{2} \mathrm{O}_{2}$ level is reasonable because this selective $\mathrm{NO}$ inhibitor is known also as antioxidant factor in both in vitro (Courderot-Masuyer et al., 1999) and in vivo (Giardino et al., 1998) conditions. AG has several functions; apart of selective iNOS inhibition (Griffiths et al., 1993; Misko et al., 1993), AG inhibits also reactive oxygen species (ROS) formation, lipids peroxidation and induced by ROS apoptosis (Giardino et al., 1998).

The levels of NO in plasma at the beginning of $T$. spiralis infection was stable (Fig. 7) but later, during muscle phase of the infection higher NO level in plasma of infected mice was observed (Fig. 8). Wandurska-Nowak and Wiśniewska, (2002) also stated higher NO level between 5 and 8 weeks post infection (wpi) in BALB/c mice. Interestingly, the level of NO in urine of infected mice during intestinal phase of the infection was lower than in uninfected mice (Fig. 9). The level of NO in urine is known as the indicator of systemic cytotoxic response activity (Granger et al., 1991). This parameter confirms the main role of Th-2 response at the beginning of $T$. spiralis infection. The second reason of the lower NO level in urine of infected mice could be caused by the renal reabsorption of nitrate (Zeballos et al., 1995). The similar reaction was observed in horses after endotoxin treatment, where also lower NO level in urine was detected despite the stable level of NO in plasma (Bueno et al., 1999). It has occurred that reabsorbed nitrates are accumulated in intracellular niches, not in blood (Zeballos et al., 1995). During the muscle phase of $T$. spiralis infection, the increase of NO level in urine of infected mice of both strains was noticed, especially in C57BL/6 mice, where the level of NO in urine of infected animals was even higher than in uninfected controls (Fig. 10). It confirms that Th-1 response is important during muscle phase of $T$. spiralis infection. Other studies showed higher IFN- $\gamma$ level and lower IL-5 level after 15 dpi in $\mathrm{BALB} / \mathrm{c}$ mice infected with $T$. spiralis, what additionally confirms the role of Th-1 response (Dvorožňáková et al., 2005). Cytotoxic activation of macrophages was also suggested by Beiting et al. (2004) who demonstrated IL-10 
participation in local inflammatory response suppression in the neighborhood of nurse-cell as well as studies where revealed strong growth of antioxidant enzymes (ex. superoxide dismutase (SOD)) level in blood and muscles (Derda \& Hadaś, 2000; Derda et al., 2004). So, it has occurred that strong inflammatory reactions provoked by the parasite in muscles activate mechanisms, which protect the host from itself tissue destruction exposed to elevated cytotoxic activity of macrophages accumulated around $T$. spiralis muscle larvae.

In conclusion, this study has shown that free radicals play role in control of $T$. spiralis infection. In the intestinal phase of $T$. spiralis infection cytotoxic immune response is activated in mice peritoneal cavity and in the muscle phase, the local immune response activated in the neighborhood of larvae in muscles appeared as the higher level of free radicals in blood and urine. Additionally, it has occurred that administration of AG between 1-5 dpi causes opposite reactions in two different strains of mice. However, it must be stressed that there are no differences between two strains of mice after treatment with AG between 16 and 29 dpi. So, our studies confirmed that the differences in host background genotype are important in activation of free radicals production as well as the responsiveness to $A G$ treatment. In low responders mice $A G$ works as an inhibitor and in BALB/c mice AG is a stimulator just after finishing injections. Mills et al., (2000) revealed that M-1/M-2 macrophages stimulated with LPS activated different way of arginine metabolism what elicited opposite effects in, for example, inflammatory reactions. Our results confirm diversity in reactivity between M-1 and M-2 macrophages expressed in different reactions of two strains of mice. Additionally, it has occurred that the roles of selective iNOS inhibitor - AG depend on the genetic background of the infected host and the phase of $T$. spiralis infection. Overall, inflammatory response in peritoneal cavity is observed later during the infection in low responders $(\mathrm{C} 57 \mathrm{BL} / 6)$ mice in comparison with high responders $(\mathrm{BALB} / \mathrm{c})$ mice. Th-1 like mice $(\mathrm{C} 57 \mathrm{BL} / 6)$ react stronger to AG treatment than Th-2 like mice (BALB/c). It occurs as changes and fluctuations in free radicals levels and the number of peritoneal cells after AG treatment in C57BL/6 mice. Weak or no reaction on $A G$ injections in $\mathrm{BALB} / \mathrm{c}$ mice is responsible for more stable and more sufficient defense response of the host to $T$. spiralis infection.

\section{Acknowledgements}

This study was supported by the Ministry of Scientific Research and Information Technology, Poland, grant No. 3 P04C 01524.

\section{References}

Alonso-Trujillo, J., Rivera-Montoya, I., RodriguezSOSA, M., TERRAZAS, L. I. (2007): Nitric oxide contributed to host resistance against experimental Taenia crassiceps cysti- cercosis. Parasitol. Res., 100: 1341 - 1350. DOI: 10.1007/s00436-006-0424-4

ANDRADE, M. A., Siles-LuCAS, M., LOPEZ-ABAN, J., Nogal-Ruiz, J. J., Perez-Arellano, J. J., MartinezFERNANDEZ, A. R., MuRO, A. (2007): Trichinella: Differing effects of antigens from encapsulated and non-encapsulated species on in vitro nitric oxide production. Vet. Parasitol., 143: 86 - 90. DOI: 10.1016/j.vetpar.2006.07.026

Beckman, J. S., Beckman, T. W., Chen, J., Marshall, P. A., Freeman, B. A. (1990): Apparent hydroxyl radical production by peroxynitrite - implications for endothelial injury from nitric-oxide and superoxide. Proc. Natl. Acad. Sci. USA, 87: 1620 - 1624

Beiting, D. P., Bliss, S. K., Schafer, D. H., Roberts, V. L., Appleton, J. A. (2004): Interleukin-10 limits local and body cavity inflammation during infection with muscle-stage Trichinella spiralis. Infect. Immun., 72: 3129 - 3137. DOI: 10.1128/IAI.72.6.3129-3137.2004

Bhattacharjee, S., Gupta, G., Bhattacharya, P., AdHIKARI, A., MAJUMdAR, S. B., MAJUMDAR, S. (2009): Anti-IL-10 mAb protection against experimental visceral leishmaniasis via induction of Th1 cytokines and nitric oxide. Indian J. Exp. Biol., 47: 489 - 497

Bian, K., Harari, Y., Zhong, M., Lai, M., Castro, G., Weisbrodt, N., Murad, F. (2001): Down-regulation of inducible nitric-oxide synthase (NOS-2) during parasiteinduced gut inflammation: a path to identify a selective NOS-2 inhibitor. Mol. Pharmacol., 59: 939 - 947

BiAn, K., ZhONG, M., HARARI, Y., LAI, M. G., WEISBRODT, N., Murad, F. (2005): Helminth regulation of host IL4R $\alpha$ /Stat6 signaling: Mechanism underlying NOS-2 inhibition by Trichinella spiralis. Proc. Natl. Acad. Sci. USA, 102: 3936 - 3941. DOI: 10.1073.pnas.0409461102

BOCZOŃ, K., WANDURSKA-NOWAK, E., WiERZBICKI, A., FRYDRYCHOWICZ, M., MOZER-LISEWSKA, I., ŻEROMSKI, J. (2004): m-RNA expression and immunohistochemical localization of inducible nitric oxide synthase (NOS-2) in the muscular niche of Trichinella spiralis. Folia Histochem. Cyto., 42: $209-213$

BogDAN, C. (2001): Nitric oxide and the immune response. Nat. Immunol., 2: 907 - 916

Brown, J. K., Donaldson, D. S., Wright, S. H., Miller, H. R. P. (2003): Mucosal mast cells and nematode infection: strain-specific differences in mast cell precursor frequency revisited. J. Helminthol., 77: 155 - 161. DOI: 10.1079/JOH2002160

Bueno, A. C., SEAhorn, T. L., Cornick-SEAhorn, J., Horohov, D. W., MoORE, R. M. (1999): Plasma and urine nitric oxide concentrations in horses given a low dose of endotoxin. Am. J. Vet. Res., 60: 969 - 976

Cabrales, P., Zanini, G. M., Meays, D., Frangos, J. A., CARVAlHO, L. J. M. (2011): Nitric oxide protection against murine cerebral malaria is associated with improved cerebral microcirculatory physiology. J. Infect. Dis., 203: 1454 1463. DOI: 10.1093/infdis/jir058

Cayatte, A. J., Palacino, J. J., Horten, K., Cohen, R. A. (1994): Chronic inhibition of nitric oxide production accelerates neointima formation and impairs endothelial 
function in hypercholesterolemic rabbits. Arterioscler. Tromb., 14: $753-759$

CoOKe, J. P., TsaO, P. H. (1992): Cellular mechanisms of atherogenesis and the effects of nitric oxide. Curr. Opin. Cardiol., 7: $799-804$

Courderot-Masuyer, C., Dalloz, F., Maupoil, V., RocheTTE, L. (1999): Antioxidant properties of aminoguanidine. Fundam. Clin. Pharmacol., 13: 535 - 540. DOI: 10.1111/j.1472-8206.1999.tb00358.x

DAI, W. J., GotTSTEIN, B. (1999): Nitric oxide - mediated immunosuppression following murine Echinococcus multilocularis infection. Immunology, 97: 107 - 116. DOI: 10.1046/j.1365-2567.1999.00723.x

DĄBROWSKA, J., WALSKI, M., GRYTNER-ZIĘCINA, B., MACHNICKA-ROWIŃSKA, B., DZIEMIAN, E., JANKOWSKASTEIFER, E. (2004): Ultrastructural analysis of capsule and nurse cell morphology examined seven months after Trichinella spiralis mouse infection (in Polish). Wiad. Parazytol., 50: 279 - 284

DERDA, M., HADAŚ, E. (2000): Antioxidants and proteolytic enzymes in experimental trichinellosis. Acta Parasitol., 45: $356-361$

DERDA, M., WANDURSKA-NoWAK, E., HADAŚ, E. (2004): Changes in the level of antioxidants in the blood from mice infected with Trichinella spiralis. Parasitol. Res., 93: 207 210. DOI: 10.1007/s00436-004-1093-9

Ding, A. H., NATHAN, C. F., STUEHR, D. J. (1988): Release of reactive nitrogen intermediates and reactive oxygen intermediates from mouse peritoneal macrophages. Comparison of activating cytokines and evidence for independent production. J. Immunol., 141: 2407 - 2412

DVOROŽŇÁKOVÁ, E., HuRNÍKOVÁ, Z., KOŁODZIEJSOBOCIŃSKA, M. (2011): Development of cellular immune response of mice to infection with low doses of Trichinella spiralis, Trichinella britovi and Trichinella pseudospiralis larvae. Parasitol. Res., 108: 169 - 176. DOI: 10.1007/s00436-010-2049-x

DVOROŽŇÁKOVÁ, E., HuRNÍKOVÁ, Z., KOŁODZIEJSOBOCIŃSKA, M. (2010): Kinetics of specific humoral immune response of mice infected with low doses of Trichinella spiralis, T. brotovi, and T. pseudospiralis larvae. Helminthologia, 47 (3): 152 - 157. DOI: 10.2478/s11687010-0023-x

DVOROŽŇÁKOVÁ, E., KOŁODZIEJ-SOBOCIŃSKA, M., HuRNíKOVÁ, Z. (2005): Development of T-cell immune response in experimental murine trichinellosis. Helminthologia, 42: 187 - 196

Eisenstein, T. K., Huang, D., Meissler, J. J. JR., AlRAMADI, B. (1994): Macrophage nitric oxide mediates immunosupression in infectious inflammation. Immunobiology, 191: 493 - 502. DOI: 10.1016/S01712985(11)80455-9

FAulKner, H., Humphreys, N., Renauld, J. C., VAN SNICK, J., GRENCIS, R. (1997): Interleukin-9 is involved in host protective immunity to intestinal nematode infection. Eur. J. Immunol., 27: 2536 - 2540. DOI: 10.1002/eji.1830271011

Garside, P., Hutton, A. K., Severn, A., Liew, F. Y., MC
MowAT, A. I. (1992): Nitric oxide mediates intestinal pathology in graft-vs.-host disease. Eur. J. Immunol., 22: 2141 - 2145. DOI: $10.1002 /$ ji. 180220827

Giardino, I., FARD, A. K., HATChELl, D. L., BrownLEE, M. (1998): Aminoguanidine inhibits reactive oxygen species formation, lipid peroxidation, and oxidant-induced apoptosis. Diabetes, 47: 1114 - 1120. DOI: 10.2337/diabetes.47.7.1114 GRANGER, D. L., HiBBS, J. B. JR., BROADNAX, L. M. (1991): Urinary nitrate excretion in relation to murine macrophage activation. Influence of dietary L-arginine and oral $\mathrm{N}^{\mathrm{G}}$ monomethyl-L-arginine. J. Immunol., 146: 1294 - 1302

Griffiths, M. J. D., Messent, M., MaC Allister, R. J., EVANS, T. W. (1993): Aminoguanidine selectively inhibits inducible nitric oxide synthase. Br. J. Pharmacol., 110: 963 968

Gruden- Movsesijan, A., Sofronic-Milosavljevic, L. (2010): Experimental trichinellosis in rats - peritoneal macrophage activity. Arch. Biol. Sci. Belgrade, 62: 15 -22. DOI: 10.2298/ABS1001015G

HelmBY, H., GRENCIS, R. K. (2003): IFN-gammaindependent effects of IL-12 during intestinal nematode infection. J. Immunol., 171: 3691 - 3696

Hogaboam, C. M., Collins, S. M., Blennerhasset, M. G. (1996): Efectes of oral L-NAME during Trichinella spiralis infection in rats. Am. J. Physiol., 271: G338 - G346

JAMES, S. L. (1995): Role of nitric oxide in parasitic infections. Microbiol. Rev. 59: 533 - 547

KARMAŃSKA, K., HousZKA, M., WidYMA, A., STEFAnIAK, E. (1997): Macrophages during infection with Trichinella spiralis in mice. Wiad. Parazytol., 43: 245 - 249

Khan ,W. I., Vallance, B. A., Blennerhassett, P. A., DenG, Y., Verdu, E. F., Matthaei, K. I., Collins, S. M. (2001): Critical role for signal transducer and activator of transcription factor 6 in mediating intestinal muscle hypercontractility and worm expulsion in Trichinella spiralis-infected mice. Infect. Immun., 69: 838 - 844. DOI: 10.1128/IAI.69.2.838-844.2001

KolB, H., Kolb-BACHOFEN, V. (1992): Nitric oxide: a pathogenic factor in autoimmunity. Immunol. Today, 13: 157 - 160. DOI: 10.1016/0167-5699(92)90118-Q

KOŁODZIEJ-SOBOCIŃSKA, M., DVOROŽŇÁKOVÁ, E., DZIEMIAN, E. (2006a): Trichinella spiralis: macrophage activity and antibody response in chronic murine infection. Exp. Parasitol., 112: 52 - 62. DOI: 10.1016/j.exppara.2005.09.004

KoŁodzIEJ-SobocińsKa, M., DZIEMIAN, E., MACHNICKARowIŃSKA, B. (2006b): Inhibition of nitric oxide production by aminoguanidine influences the number of Trichinella spiralis parasites in infected "low responders" (C57BL/6) and "high responders" (BALB/c) mice. Parasitol. Res., 99: 194 - 196. DOI: 10.1007/s00436-0060144-9

KOŁODZIEJ-SOBOCIŃSKA, M., DVOROŽŇÁKOVÁ, E., DZIEMIAN, E., MACHNICKA-ROWIŃSKA, B. (2007): Trichinella spiralis reinfection: macrophage activity in BALB/c mice. Parasitol. Res., 101: 629 - 637. DOI: 10.1007/s00436-007-0527-6

LIEW, F. Y. (1993): The role of nitric oxide in parasitic 
diseases. Ann. Trop. Med. Parasitol., 87: 637 - 642

Liew, F.Y., Millott ,S., Parkinson, C., Palmer, R.M., MONCADA, S. (1990): Macrophage killing of Leishmania parasite in vivo is mediated by nitric oxide from L-arginine. J. Immunol., 144: 4794 - 4797

Liew, F. Y., WeI, X. Q., Proudfoot, L. (1997): Cytokines and nitric oxide as effector molecules against parasitic infections. Phil. Trans. R. Soc. Lond. B., 352: 1311 - 1315

Luss, H., Di Silvio, M., LitTon, A. L., Molina, Y., Vedia, L., NusSLER, A. K., BILliAR, T. R. (1994): Inhibition of nitric oxide synthesis enhances the expression of inducible nitric oxide synthase mRNA and protein in a model of chronic liver inflammation. Biochem. Biophys. Res. Commun., 204: 635 - 640. DOI: 10.1006/bbrc.1994.2506

Luss, H., Li, R. K., Shapiro, R. A., TzENG, E., MC Gowan, F. X., Yoneyama, T., Hatakeyama, K., Geller, D. A., Mickle, D. A., Simmons, R. L., Billiar, T. R. (1997): Differentiated human ventricular cardiac myocytes express inducible nitric oxide synthase mRNA but not protein in response to IL-1, TNF, IFN-gamma, and LPS. J. Mol. Cell. Cardiol., 29: 1153 - 1165. DOI: 10.1006/jmcc.1996.0349 Mills, C. D., Kincaid, K., Alt, J. M., Heilman, M. J., Hill, A. M. (2000): M-1 / M-2 macrophages and the Th1/Th2 paradigm. J. Immunol., 164: 6166-6173

Misko, T. P., Moore, W. M., Kasten, T. P., Nickols, G. A., Corbett, J. A., Tilton, R. G., MC Daniel, M. L., Williamson, J. R., Currie, M. G. (1993): Selective inhibition of the inducible nitric oxide synthase by aminoguanidine. Eur. J. Pharmacol., 233: 119 - 125. DOI: 10.1016/0014-2999(93)90357-N

MORLEY, J. E., FlOOD, J. F. (1991): Evidence that nitric oxide modulates food intake in mice. Life Sci., 49: 707 - 711 Olesen, J., ThOMSEN, L. L., IVERSEN, H. (1994): Nitric oxide is a key molecule in migraine and other vascular headaches. Trends Pharmacol. Sci., 15: 149 - 153. DOI: 10.1016/01656147(94)90075-2

Pacelli, R., Wink, D. A., CoOK, J. A., Krishna, M. C., DeGraff, W., Friedman, N., Tsokos, M., Samuni, A., MitCHELL, J. B. (1995): Nitric oxide potentates hydrogen peroxide-induced killing of Escherichia coli. J. Exp. Med., 182: 1469 - 1479

Pacher, P., Beckman, J. S., Liaudet, L. (2007): Nitric oxide and peroxynitrite in health and disease. Physiol. Rev., 87: 315 - 424. DOI: 10.1152/physrev.00029.2006

PICK, E. (1986): Microassays for superoxide and hydrogen peroxide production and nitroblue tetrazolium reduction using an enzyme immunoassay microplate reader. Methods Enzymol., 132: 407 - 421. DOI: 10.1016/S00766879(86)32026-3

Rajan, T. V., Porte, P., Yates, J. A., Keefer, L., Shultz, L. D. (1996): Role of nitric oxide in host defense against extracellular metazoan parasite Brugia malayi. Infect. Immun., 64: 3351 - 3353

REITEROVÁ, K., DUBINSKÝ, P., KLIMENKO, V.V., TOMAŠOVIČOVÁ, O., DVOROŽŇÁKOVÁ, E. (1999): Comparison of Trichinella spiralis larva antigens for the detection of specific antibodies in pigs. Veterinarni Med., 44 (1): $1-5$

Ren, G., Zhang, L., ZHAO, X., XU, G., ZhANG, Y., RoBerts, A. I., ZHAO, R. CH., SHI, Y. (2008): Mesenchymal stem cellmediated immunosupression occurs via concerted action of chemokines and nitric oxide. Cell Stem Cell, 2: 141 - 150. DOI: 10.1016/j.stem.2007.11.014

Rockett, K. A., Awburn, M. M., Rockett, E. J., Cowden, W. B., Clark, I. A. (1994): Possible role of nitric oxide in malarial immunosuppression. Parasite Immunol., 16: 243 249. DOI: 10.1111/j.1365-3024.1994.tb00346.x

Shanta, C. S., MeErovich, E. (1967): The life cycle of Trichinella spiralis. II. The muscle phase of development and its possible evolution. Can. J. Zool., 45: 1261 - 1267

Singh, V. K., Mehrotra, S., Narayan, P., Pandey, C. M., AGARWAL, S. S. (2000): Modulation of autoimmune diseases by nitric oxide. Immunol. Res., 22: 1 - 19. DOI: 10.1385/IR:22:1:1

Urban, J. F., Schopf, L., Morris, S. C., Orekhova, T., Madden, K. B., Betts, C. J., Gamble, H. R., Byrd, C., Donaldson, D., Else, K., Finkelman, F. D. (2000): Stat6 signaling promotes protective immunity against Trichinella spiralis through a mast cell- and $\mathrm{T}$ cell-dependent mechanism. J. Immunol., 164: 2046 - 2052

WANDURSKA-NOWAK, E., WIŚNIEWSKA, J. (2002): Release of nitric oxide during experimental trichinellosis in mice. Parasitol. Res., 88: 708 - 711. DOI: 10.1007/s00436-0020631-6

Zeballos, G. A., Bernstein, R. D., Thompson, C. I., Forfia, P. R., Seyedi, N., Shen, W., KAMInski, P. M., Wolin, M. S., Hintze,T. H. (1995): Pharmacodynamics of plasma nitrate/nitrite as an indicator of nitric oxide formation in conscious dogs. Circulation, 91: $2982-2988$

ZHU, L., GunN, C., BeCKMAN, J. S. (1992): Bactericidal activity of peroxynitrite. Arch. Biochem. Biophys., 298: 452 -457. DOI: 10.1016/0003-9861(92)90434-X 